\title{
HEALTH BELIEF MODEL ON THE DETERMINANTS OF SELF CARE AMONG PATIENTS WITH TYPE 2 DIABETES MELLITUS
}

\author{
Ummy Prasetyowati'), Didik Tamtomo), Bhisma Murti1) \\ 1)Masters Program in Public Health, Universitas Sebelas Maret \\ 2)Faculty of Medicine, Universitas Sebelas Maret
}

\begin{abstract}
Background: Promoting self-care and self-management behaviors among patients with type 2 diabetes mellitus-related have been associated with improved clinical outcomes, fewer complications, enhanced glycaemic control, and quality of life. This study aimed to analyze the determinants of self care among patients with type 2 diabetes mellitus, using Health Belief Model.

Subjects and Method: This was a cross sectional study carried out at Dr. Moewardi Hospital, Surakarta, Central Java, from March to April 2018. A sample of 200 type 2 diabetes mellitus patients was selected by total sampling. The dependent variable was self preventive care. The independent variables were perceived severity, perceived susceptibility, and cues to action. The data were collected by questionnaire and analyzed by a multiple logistic regression.

Results: Self preventive care in type 2 diabetes mellitus increased with strong perceived susceptibility $(\mathrm{OR}=2.56 ; 95 \% \mathrm{CI}=1.11$ to $5.91 ; \mathrm{p}=0.027)$, strong perceived severity $(\mathrm{OR}=6.56 ; 95 \% \mathrm{CI}=3.03$ to $14.22 ; \mathrm{p}<0.001)$, and cues to action $(\mathrm{OR}=4.38 ; 95 \% \mathrm{CI}=1.81$ to $10.56 ; \mathrm{p}<0.001)$.

Conclusion: Self preventive care in type 2 diabetes mellitus increases with perceived susceptibility, perceived severity, and cues to action.
\end{abstract}

Keywords: type 2 diabetes mellitus, self preventive care, health belief model

\section{Correspondence:}

Ummy Prasetyowati. Masters Program in Public Health, Universitas Sebelas Maret, Jl. Ir. Sutami 36A, Surakarta 57126, Central Java.

Email: ummyprasetyowati@gmail.com. Mobile: +6281227225939.

The 4th International Conference on Public Health

Best Western Premier Hotel, Solo, Indonesia, August 29-30, 2018 | 161 https://doi.org/10.26911/theicph.2018.02.42 